\title{
Large-scale cartographical model of ampelo-ecological division into districts
}

\author{
V. Vlasov, \\ Corresponding Member of the National Academy of Sciences of Ukraine, Doctor of Agricultural \\ Sciences \\ G. Liashenko, Doctor of Geographical Sciences \\ M. Buzovskaya, \\ Candidate of Agricultural Sciences \\ Yu. Bulayeva \\ NSC " V.Ye. Tairov Institute of viticulture and winemaking"
}

The purpose. To develop large-scale cartographical model based on regularities of geographic distribution of indexes of ampelo-ecological conditions in wine growing zone of Ukraine. Methods. Geographical analysis (study of regularities of geographic distribution of indexes of ecological conditions); cartographical (development of ampelo-ecological characteristics of terrain); field (determination of ampelo-landscape characteristics of terrain); modeling (study of link of a state of a grape and ecological conditions). Results. Algorithm of large-scale cartographical model is developed. On an instance of lands of some villages of the South of Ukraine with significant percentage of vineyards modeling is realized and large-scale maps of ampelo-ecological division into districts are made. Verification of large-scale cartographical model is carried out in Volnensk (Tarutinsk area of Odessa oblast). Conclusions. Developed algorithm of ampelo-ecological mapping and large-scale cartographical model of ampelo-ecological division into districts of the South of Ukraine can be used at optimization of wine growing branch.

Key words: ecological conditions, grape, ampelo-ecotope, ampelo-ecological assessment, algorithm of ampeloecological mapping, large-scale cartographical model.

Relevance and research experience in the world. Rational and effective management in the viticulture requires the processing and analysis of a large number of various information.

The scientists of the National Scientific Centre "V.Ye. Tairov Institute of Viticulture and Wine-Making" performed an ampeloecological zoning of the territory of the Northern Black Sea Region with the allocation of ampeloecological niches, where 12 ampelecological districts (from the Danube to the Dnieper) within the zone of viticulture, for which the optimum variety split was recommended by maturation and frost resistance terms. The next task is to elaborate the ampeloecological information, which includes spatial detalization of the relief elements, soil and climate (microclimate), and the spatial detalization of the productivity of vineyards at the level of the individual, homogeneous ecological conditions of the territorial parts - ampeloecotopes. Effective presentation of such comprehensive information can only be carried out using cartographic models. Moreover, the efficiency increases with an increase in the scale of mapping, and the possibility of large-scale mapping, in turn, increases with a decrease in the physical size of the investigated area: the Northern Black Sea Region, administrative regions, administrative districts, lands of village or settlement councils, individual farms or collective farms. Scale mapping can increase from 1:750000 to 1:10000 and even more.

The first studies devoted to cartographic modeling were conducted in the 70's and 80's under the guidance of an outstanding cartographer K. O. Salischev. Subsequently, they were continued in various scientific institutions of geography and ecology, in particular, when mapping agro-climatic resources taking into account their microclimatic zone $[5,7]$.

Target setting. One of the approaches to optimizing the location of grape plantations is the ampeloecological assessment of the territories, which aims at allocating plots with optimal ecological conditions (ampeloecotopes), where a particular cultivar fully reveals its natural potential. The most effective method of research is the study of the connection between the state of grapes and environmental conditions, on the basis of which models are developed. While assessing the ecological conditions of the territory much attention is paid to large-scale mapping of individual indicators of ampeloecological resources. First of all, it is a mapping of indicators that characterize the elements of the relief, soil and agro-climatic conditions. In future, the assembly operation of integrated synthetic ampeloecological maps is being compiled. 
These maps are an important source of information and a tool of its accumulation, analysis and synthesis. Besides, large-scale ampelocological maps are used while solving the issues of placement, specialization and sorting of grapes, the development of vineyard planting projects, which will ensure the effective use of the ampeloecological potential of a particular area, and subsequently obtaining vinicultural products of the proper quality.

The scientists of the National Scientific Centre "V.Ye. Tairov Institute of Viticulture and Wine-Making" performed an ampeloecological zoning of the territory of the Northern Black Sea Region with the allocation of ampeloecological niches, where 12 ampelecological meso-districts (from the Danube to the Dnieper) within the zone of viticulture, for which the optimum variety split was recommended by maturation and frost resistance terms.

Goal of research is to develop a large-scale cartographic model based on the principles of the geographical distribution of environmental conditions in the viticultural zone of Ukraine.

Materials and research methods. The research purposes are aimed at establishing the patterns of spatial variation of ampeloecological conditions. Their discovery and inventory are carried out using the cartographic method. As the final result we obtain a cartographic interpretation of the complex of ampeloecological factors, that is, thematic and complex large-scale maps. When compiling any thematic map, the gradation of indicators of the group of environmental conditions will be carried out on the basis of known bioecological passports of various grape cultivars.

For objective multi-factor analysis, ampelecological assessment of the territory of the Northern Black Sea Region and the compilation of large-scale maps, GIS (ArcGIS) was used [11]. The verification of a large-scale cartographic model was carried out in the basic vineyard of Odessa region. The topographic and soil maps, maps of agro-industrial groupings of soils have become the information base for the development of a largescale cartographic model of ampeloecological zoning with the accompanying materials of the State Enterprise "Odessa Research and Design Institute of Land Management».

Research results. At present time model engineering is a modern method of research in various fields of knowledge, including viticulture. Cartographic modeling is one of the fundamental concepts of modeling of physical and biophysical processes, and is the basis for studying complex systems, including agroecosystems. Cartographic modeling shall mean the creation, analysis, mapping, the object of which serves is a distinct attributive and ampeloecological information. Cartographic modeling reproduces the essence of the object, its qualitative and quantitative characteristics and structure. The map is made up of the technological rules of the mapping work, starting with the choice of the original or typical mathematical basis of the map, elements of the general geographic basis, which are not only the basis for drawing elements of special content, but they also must emphasize the nature of the object of modeling $[1,4,8]$.

The exploratory researches of ampelocosystems are carried out and there was presented the first cartographic model on which the identification of ampelocotopes in the spatial and territorial section was carried out. Figure 1 shows the stages of cartographic modeling of ampeloecological zoning in the South of Ukraine.

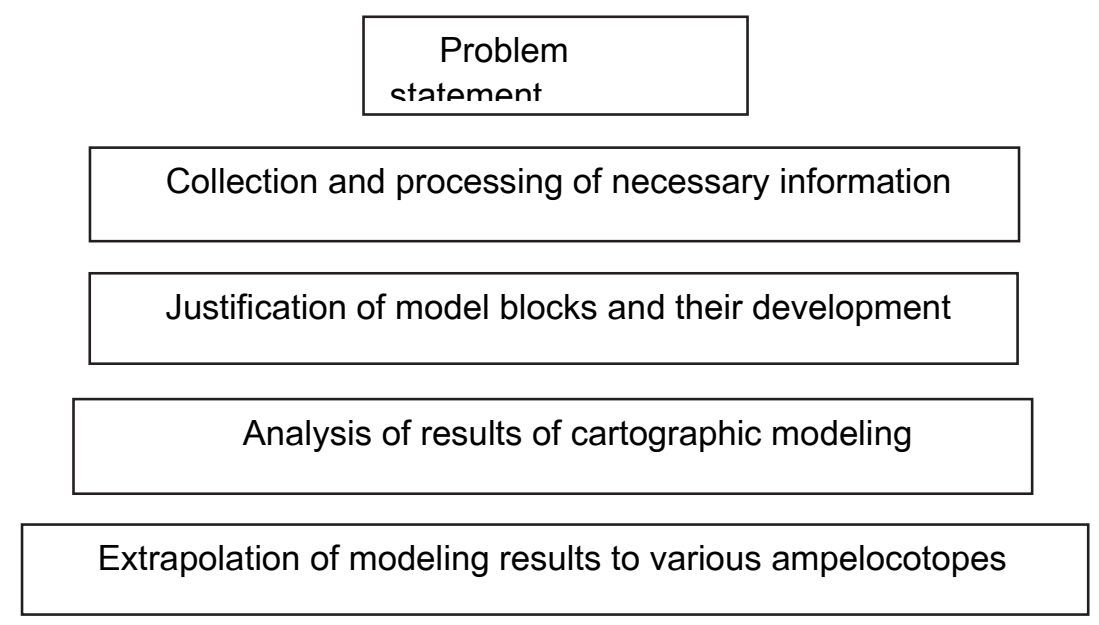

Figure 1. Stages of cartographic modeling of ampeloecological zoning 
The principle of systemicity is observed at all stages of research, especially at the design stages, mapping, image generalization, legend design, selection of sign systems, evaluation of existing maps for their compliance with the object, etc. The principle of systemicity extends to the geographic information sphere of cartographic modeling, which involves the classification of objects, the composition of the database, the system of mapping indicators.

Depending on the scale of searches, three types of ampelecological models (maps) are distinguished: large-scale (including detailed ones), intermediate-scale and small-scale. Depending on the complexity and variability of the environmental conditions of a particular territory, ampelecological maps comprise scales of 1:10000 (large-scale) or 1:5000 and 1:2000 (detailed) [3, 9, 10].

Mapping of such scales is a starting point and is used for the compilation of other types of maps of smaller scale. The algorithm of large-scale cartographic modeling for ampeloecological resources of the South of Ukraine is presented in Fig. 2. The algorithm of large-scale cartographic modeling is to substantiate the factors and indices of ampeloecological resources and the order of their determination, the choice of the calculation model and the actual cartographic modeling.

The large-scale cartographic model of the ampeloecological zoning of the South of Ukraine includes an integrated indicator of the state of the vineyard at each point of the territory, which is a function of various factors and indicators of ampelo-environmental conditions:

$$
\begin{aligned}
Y_{\varphi \lambda h} & =f\left(x_{i}^{j} \cdot x_{i}^{j} \cdot x_{i}^{j}, \ldots, \cdot x_{n}^{k}\right) \\
Y_{\varphi \lambda h} & =f\left(x_{i}^{j} \pm x_{i}^{j} \pm x_{i}^{j}, \ldots, \pm x_{n}^{k}\right)
\end{aligned}
$$

where, $\mathrm{Y}$ - state of the vineyard, $\lambda$ - longitude; $\varphi$ - latitude; $\mathrm{h}$ - height; $\mathrm{f}$ - function; $\mathrm{i}$ - factors and indices of ampeloecological conditions ( $\triangle \mathrm{h}, \mathrm{F}, \mathrm{E}, \ell, \mathrm{SC}, \mathrm{HC}, \mathrm{CAC}, \mathrm{GWDL}, \Sigma \mathrm{T}, \mathrm{T}$ av. min); j - class (intensity) of each of these factors; $\Delta \mathrm{h}$ - relative elevation altitude; $\mathrm{F}$ - forms of relief;

$\mathrm{E}$ - slope exposure; $\ell$ - slope; SC - soil mantle; HC - humus content, t/ha; CAC - content of active carbonates, \%; GWDL - ground water depth level, $\mathrm{m}, \Sigma \mathrm{T}$ - sum of temperatures; $\mathrm{T}$ av. min - minimum temperatures.

Subsequently, a verification of the large-scale cartographic model was carried out on the viticultural and winemaking territory of Odessa region by geographical coordinates (latitude and longitude) and the relative elevation of the territory, altitude above sea level. To develop a large-scale mapping model of ampeloecological zoning, we use large-scale, single-factor ampeloecological maps (relief, soil, and microclimate [6]). In the process of cartographic synthesis of ampeloecological maps, there is a revaluation of individual factors and the allocation of territories that are homogeneous in a complex of environmental conditions (Figure 3) [2]. 


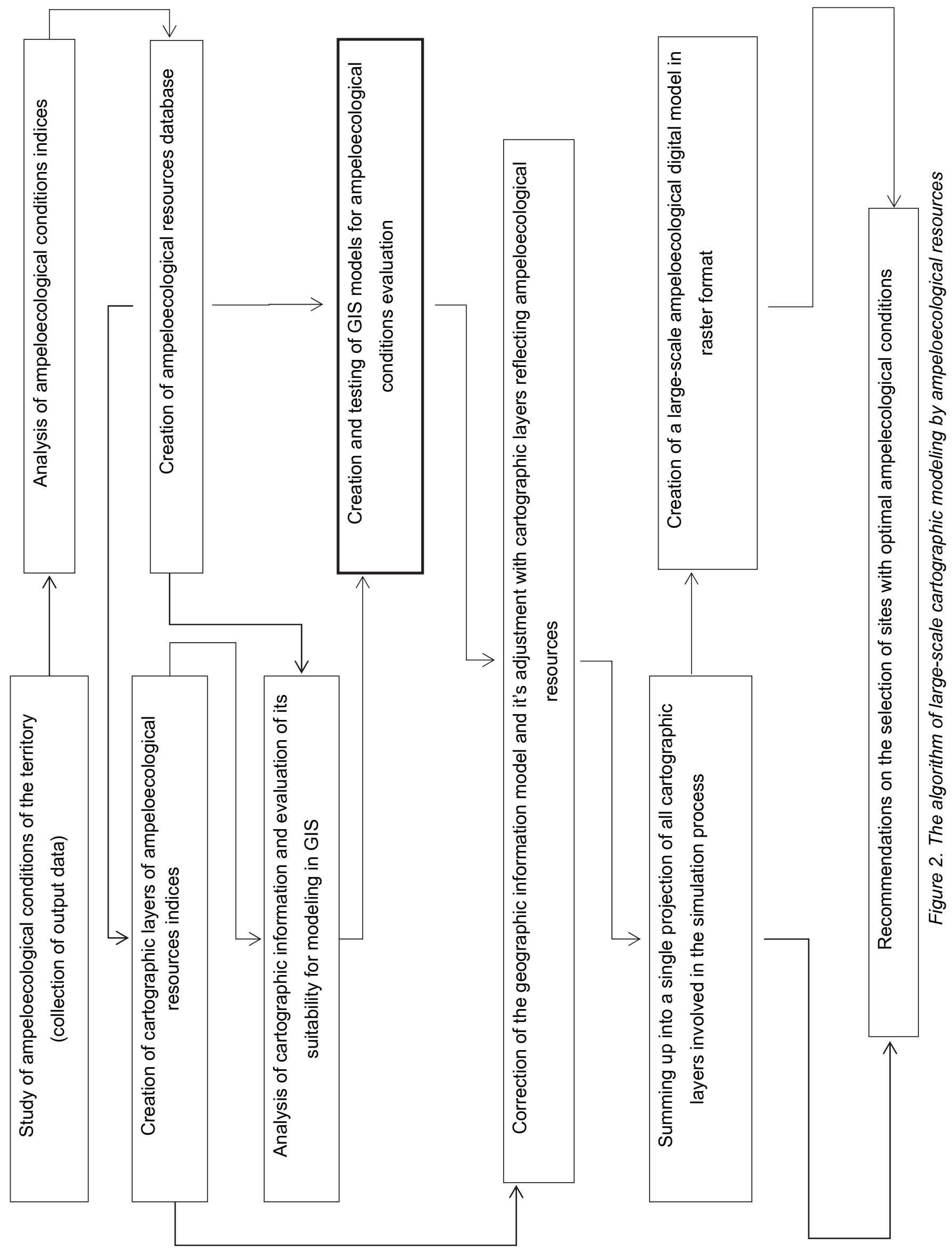




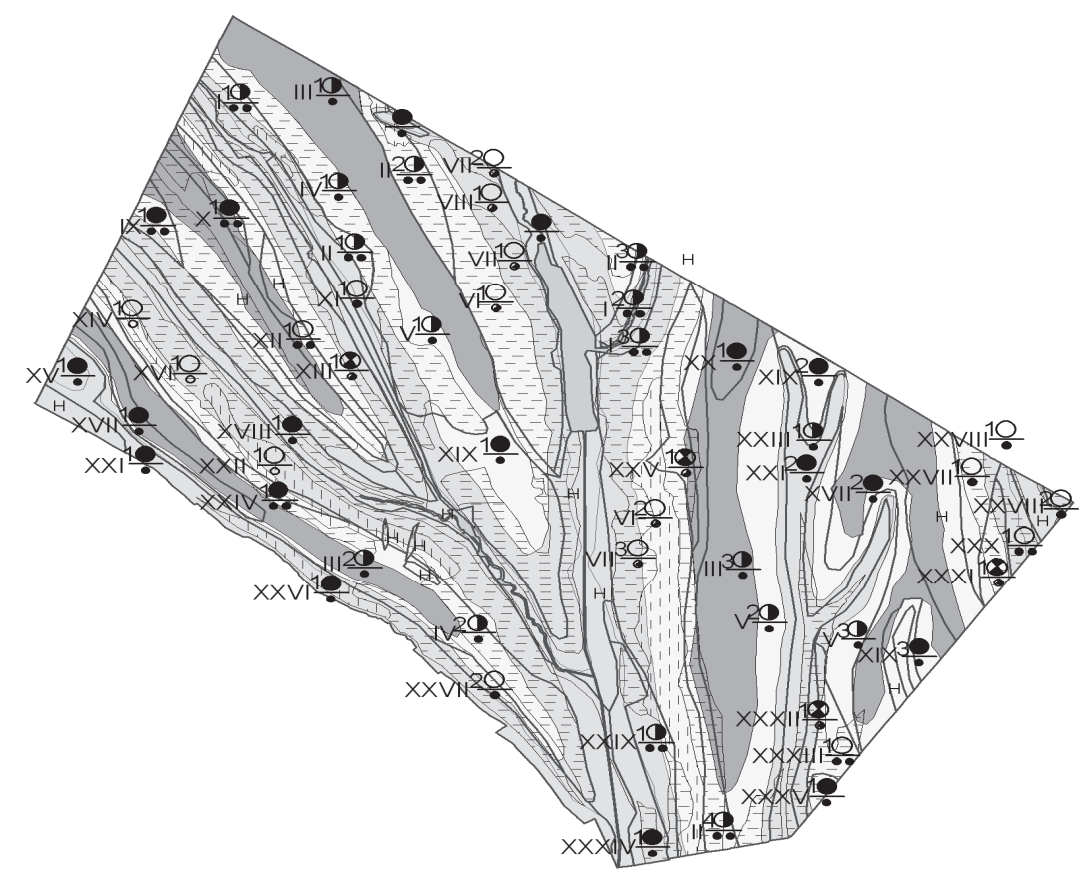

Figure 3. The complex ampeloecological map of Vilne Village Council of the Tarutino district (from I to XXXV numbers of ampeloecotopes)

\begin{tabular}{|c|c|c|c|c|c|}
\hline \multicolumn{5}{|c|}{$\begin{array}{c}\text { Charachteristics of ampeloecotopes by humus content, content of active carbonates and soil } \\
\text { texture in } 1 \text { meter layer }\end{array}$} & \multirow[t]{3}{*}{$\begin{array}{l}\text { Number } 0 \\
\text { agrogroup }\end{array}$} \\
\hline \multirow[t]{2}{*}{ Sign } & \multirow{2}{*}{$\begin{array}{l}\text { Content of active } \\
\text { carbonates }\end{array}$} & \multirow[t]{2}{*}{ Humus content } & \multicolumn{2}{|r|}{ Soil texture } & \\
\hline & & & Sign & According to Kachinsky & \\
\hline & \multirow{9}{*}{$4.0-10.5$} & \multirow{4}{*}{$100-200$} & $\mathrm{O}$ & light loam (sandy clay loam) & $65 \mathrm{~g}$ \\
\hline & & & 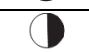 & medium loam (sandy clay) & $65 d$ \\
\hline & & & $\sqrt{3}$ & heavy loam (sandy clay, loam) & $66 \mathrm{e}$ \\
\hline & & & & clay & 861 \\
\hline & & \multirow{2}{*}{$200-300$} & & heavy loam (sandy clay, loam) & $65 \mathrm{e}$ \\
\hline & & & & clay & 851 \\
\hline & & \multirow{2}{*}{ more than 300} & & heavy loam (sandy clay, loam) & $61 e, 209 e$ \\
\hline & & & 0 & clay & $82 e$ \\
\hline & & less than 100 & (2) & loamy sand, sandy loam & $92 v, 93 v$ \\
\hline
\end{tabular}

\begin{tabular}{|c|c|c|c|}
\hline Sign & Slope, degrees & Area, ha & Type of territory's planning \\
\hline & $0-3$ & 3065 & Straight-line placement of all elements \\
\hline
\end{tabular}

Temperature from -17.5 to $-20.0^{\circ} \mathrm{C}$

Temperature from -20.0 to $-22.5^{\circ} \mathrm{C}$

Temperature from -22.5 to $-25.0^{\circ} \mathrm{C}$

Temperature from $-25.0^{\circ} \mathrm{C}$ and lower 


\section{Conclusions}

The detailed analysis of the ampelecological situation in the winemaking regions of the South of Ukraine was carried out and the optimal indices of ampeloecological conditions are substantiated. The algorithm for ampeloecological mapping and a large-scale cartographic model of ampeloecological zoning for the studied territory was developed. The verification of the large-scale cartographic model was carried out as exemplified by the basic farm of the Vilne Village Council of the Tarutino district of Odessa region. The reliability of the developed model reaches $90 \%$ on average.

\section{Bibliography}

1. Benedikt EH. Kartograficheskoe modelirovanie $v$ izuchenii antropogennogo izmeneniya prirodnyh resursov/EH. Benedikt, T. G. Nefedova, G. Fridlajn//lzv. AN SSSR. Seriya geograf. — 1987. — № 3. — S. $137-142$.

2. Vlasov V.V. Ahroekolohichne obgruntuvannya rozmishchennya vynohradnykiv z vykorystannyam HIStekhnolohiy/V.V. Vlasov, O.Yu. Vlasova, V.V. Omel'chenko//Vynohradarstvo i vynorobstvo: mizhv. tem. nauk. zb. Odesa: Optimum, 2006. - Vyp. 43. - S. 5-12.

3. Godel'man YA.M. Teoriya, metody i praktika ampeloehkologicheskoj klassifikacii i kartografii zemel'/YA.M. Godel'man. - Kishinev: SHtiinca, 1983. - S. 3-42.

4. Isachenko A.G. EHkologicheskie problemy i ehkologo-geograficheskoe kartografirovanie SSSR/A.G. Isachenko//Izvestiya VGO. - 1990. - T. 122. - Vyp. 4. - S. $289-301$.

5. Lyashenko H.V. Metodyka otsinky ahroklimatychnykh resursiv ta yikh kartohrafuvannya z vrakhuvannyam mikroklimatu/H.V. Lyashenko. — Odesa: NNTs «IViV im. V.Ye. Tayirova», 2009. — $58 \mathrm{~s}$.

6. Mishchenko Z.A. Krupnomasshtabnoe kartografirovanie mikroklimata po usloviyam zamorozkoi morozoopasnosti/Z.A. Mishchenko, G.V. Lyashenko//Sb. biolog. i him. nauk. — Kishinev: Izd-vo AN MSSR. — 1990. - № 3. - S. 60 - 72.

7. Svetlichnyj A.A. Geograficheskie informacionnye sistemy: tekhnologii i prilozheniya/A.A. Svetlichnyj, V.M. Anderson, S.V. Plotnickij; pod red. G.I. SHvebsa. — Odesca: Astroprint, 1997. — 200 s.

8. YAkovenko I.M. Rekreacionnoe prirodopol'zovanie: metodologiya i metodika issledovanij/l.M. YAkovenko. Simferopol': Tavriya, 2003. - 335 s.

9. Eastman J.R. IDRISI: A Grid-Based Geographic Analysis System/J.R. Eastman//Clark University of Geography, Graduate School of Geography. - 362 p.

10. Kitchin R. Conducting research in Human Geography/R. Kitchin, N. Tate//Harlow (UK): Pearson Education Limited, 2000. - $370 \mathrm{p}$. 